\section{๑๑}

Received: 03 October 2016

Accepted: 12 January 2017

*Corresponding author: Wondwesen Tafesse, School of Business and

Economics, UIT the Arctic University of

Norway, Post Box 6050 Langnes, 9037 Troms $\varnothing$, Norway

E-mail: wondwesen.tafesse@uit.no

Reviewing editor:

Len Tiu Wright, University of

Huddersfield, UK

Additional information is available at the end of the article

MARKETING | RESEARCH ARTICLE

\title{
A framework for categorizing social media posts
}

Wondwesen Tafesse ${ }^{1 *}$ and Anders Wien ${ }^{1}$

Abstract: Brand posts are concise and recurrent updates created by brands and sent out to their followers on social media. Brand posts play a crucial linking role by connecting brands to their customers and fans on a daily basis. Brand posts represent a rich form of communication that convey various brand meaning and experiences using multiple media formats. Despite this, however, brand posts have not been subjected to formalized analyses in the literature. Accordingly, the purpose of this study is to conduct a formalized analysis of brand posts and propose a systematic framework to categorize them. With this aim, the study performed qualitative content analysis involving three interrelated coding procedures. First, the study reviewed the relevant literature to identify pre-existing coding categories (deductive coding). Second, the study drew together systematic inferences from a purposive sample of brand posts ( $n=371$ ) to derive new coding categories (inductive coding). Finally, the study implemented a double-coding procedure on a probabilistic sample of brand posts ( $n=249$ ) to validate the initial coding categories (validation coding). Together, the three coding procedures produced 12 exhaustive and mutually exclusive categories of brand posts. The proposed categorization offers a comprehensive framework to think about brand posts. For marketers, it provides guidance to create the stream of content necessary to stimulate daily customer interaction on social media. For researchers, it offers a solid conceptual foundation to categorize, code and model brand posts.

\section{ABOUT THE AUTHORS}

Both authors belong to the Arctic University of Norway, the School of Business and Economics, Department of Marketing, where Wondwesen Tafesse is a postdoctoral researcher and Anders Wien is an associate professor. Both authors are interested in social media marketing, and how consumers engage with and respond to marketers' efforts on social media. Wondwesen Tafesse has published his research in renowned marketing journals, such as Industrial Marketing Management and European Journal of Marketing, among others. Likewise, Anders Wien has published his research in renowned marketing journals, such as Psychology \& Marketing and European Journal of Marketing, among others. Both authors have teaching responsibilities and are involved in the mentorship and supervision of graduate students.

\section{PUBLIC INTEREST STATEMENT}

Social media marketing involves establishing brand pages on social media and posting a variety of content (i.e. brand posts) for fans and followers. This study provides a systematic framework to analyze and classify brand posts into different categories according to their message strategy. The proposed framework presents a rich description of 12 distinct categories of brand posts that are commonly encountered across corporate and business brand pages. The development of these categories allows social media marketers to appreciate the extensive scope of brand pages for brand communication and customer interaction on social media. Social media marketers can use the proposed framework to generate brand post ideas and experiment with different message strategies. They can also combine distinct message strategies to design combined brand posts. In short, the proposed categorization offers a managerially meaningful framework to think about brand posts and manage them more effectively. 


\title{
Subjects: Internet/Digital Marketing/e-Marketing; Marketing Communications; Relationship Marketing
}

\author{
Keywords: social media marketing; content marketing; content strategy; brand pages; \\ brand posts; facebook
}

\section{Introduction}

Social media represent web-based and mobile interactive applications that support user-generated content and real-time interactions based on friendship or overlapping interests (Kaplan \& Haenlein, 2010). Social media enable users to create personalized profiles, present themselves publicly and interact with other users along dyadic and network ties (Berthon, Pitt, Plangger, \& Shapiro, 2012; Peters, Chen, Kaplan, Ognibeni, \& Pauwels, 2013). Due to their mass appeal and network externality, social media platforms such as Facebook, YouTube and LinkedIn have experienced exponential growth in their user base (Kietzmann, Hermkens, McCarthy, \& Silvestre, 2011; Lin \& Lu, 2011). On Facebook alone, the number of active monthly users has surpassed 1.5 billion by the end of 2015 (Facebook, 2015).

To capitalize on their growing popularity, brands are increasingly implementing social media marketing, which involves exploiting the interactive and networking capabilities of social media to marketing ends (Mangold \& Faulds, 2009). An essential component of social media marketing is brand pages, which represent an interactive platform established by brands on social media to connect with their customers and fans (Lipsman, Mudd, Rich, \& Bruich, 2012). Brand pages allow brands to build an online community and interact with them on an on-going basis (Zaglia, 2013). At the heart of brand pages are brand posts-a relatively frequent, concise and (mostly) unpaid for updates created by brands and sent out to their followers on a daily basis. Brand posts are a rich form of communication that facilitate a variety of brand meaning and experiences (Tafesse, 2016). The interactive capability of brand posts coupled with their ability to support multiple media types (e.g. text, photo, video and website links), offers marketers an unprecedented scope to experiment with a variety of messages (Ashley \& Tuten, 2015). Yet, despite this, relatively little is known about the various categories of brand posts that marketers publish on their brand pages. Brand posts are largely analyzed and classified in an ad hoc manner.

Accordingly, the purpose of this study is to develop a formalized framework for the categorization of brand posts which draws on the concept of message strategy as a guiding template. Message strategy deals with the problem of how to frame a marketing message, so that the message can be received positively among the target audience and desired marketing outcomes can be achieved (Puto \& Wells, 1984; Taylor, 1999). Message strategy has proved instrumental in the advertising literature to analyze and classify advertising content into generalized typologies (e.g. Laskey, Day, \& Crask, 1989).

Empirically, the study draws on qualitative content analysis, which is a systematic approach to make valid inferences from data (Zhang \& Wildemuth, 2009). Qualitative content analysis is particularly expedient in condensing a large volume of data into conceptually meaningful categories (Hsieh \& Shannon, 2005). Specifically, the current study implemented a combination of deductive, inductive, and validation coding. The deductive coding combined a review of the advertising literature and the social media literature to identify pre-existing brand post categories. The inductive coding drew together systematic inferences from a purposive sample of brand posts $(n=371)$ to derive new brand post categories. Together, these two coding procedures identified 12 categories of brand posts, which were subsequently validated on a probabilistic sample of brand posts using a doublecoding procedure $(n=249)$. Thus, the proposed categorization encompasses 12 categories of brand posts, with each category specifically defined and its conceptual and empirical boundaries clearly established. The proposed categorization offers a comprehensive framework to think about brand posts. For marketers, it provides guidance to create the stream of content necessary to stimulate daily social media interaction with customers and fans. For researchers, it offers a solid foundation to analyze and code brand posts and test their effect on brand outcome variables. 


\section{Literature review}

\subsection{Message strategy}

Message strategy is a guiding principle that determines the content domain of a branded content, such as a piece of advertising or a brand post (Puto \& Wells, 1984). Message strategy aligns the nature and character of branded content with consumers' specific needs, thereby bridging the gap between what marketers want to say and what consumers need to hear (Laskey et al., 1989; Taylor, 1999). Message strategy is a principle used to frame marketing messages such that the messages are well received and achieve desired effects in the target audience (Puto \& Wells, 1984). Marketers maintain a high level of interest in message strategy because of its importance for advertising results and the control they have over its design and execution (Ashley \& Tuten, 2015). Message strategy has supplied a useful template for the analysis and classification of advertising content into generalized typologies.

In a pioneering work, Puto and Wells (1984) broadly distinguished between informational vs. transformational advertising. Informational advertising is defined as one which provides consumers with factual, relevant brand data in a clear and logical manner such that consumers have greater confidence in their ability to assess the functional attributes of products and services. Transformational advertising is defined as one which associates the experience of using a product or service with a unique set of psychological characteristics. Transformational advertising transforms the experience of using the brand by endowing this use with a particular experience that is different from that of using any similar brand. Puto and Wells (1984) then grouped advertising content as belonging to one of four basic categories: (1) High Transformation-Low Information, (2) Low Transformation-High Information, (3) High Transformation-High Information, and (4) Low Transformation-Low Information.

Likewise, Laskey et al. (1989) proposed an influential typology based on two broad advertising dichotomies: informational vs. transformational. Within these two dichotomies, the authors incorporated several specific message strategies including comparative, unique selling proposition, preemptive, hyperbole and generic (informational); and user image, brand image and use occasion (transformational). The informational message strategy emphasizes the functional attributes of products and services, while the transformational message strategy emphasizes the hedonic qualities of products and services. Similarly, Taylor (1999) developed another widely cited typology. Drawing on theories of mass communication and consumer behavior, the author espoused two broad advertising dichotomies: transmission vs. ritual. The transmission-based message strategy (i.e. comparative, generic, pre-emptive, unique selling proposition, brand familiarity, and hyperbole) appeals to consumers' need for functional information, while the ritual-based message strategy (i.e. affective, user image, resonance, and use occasion) appeals to consumers' need for emotional fulfillment, social approval, and sensory stimulation.

The foregoing typologies draw attention to the broad scope of message strategies at marketers' disposal to design and execute tailored advertising. Importantly, the typologies can provide a solid foundation to analyze and categorize brand posts since the basic creative principles that underpin traditional advertising (e.g. rational vs. emotional appeals) are translatable to online environments (Ashley \& Tuten, 2015). Indeed, the typologies have been replicated in online contexts involving banner ads, signifying their transferability to online platforms (e.g. Golan \& Zaidner, 2008). As such, some of the proposed message strategies (e.g. emotional, functional, experiential and brand resonance) can be applicable to brand posts (Swani, Brown, \& Milne, 2014). However, traditional message strategies are not anticipated to span the entire spectrum of brand posts. The recurrence, interactivity and multi-media affordances of brand posts mean they can support a far wider assortment of message strategies than traditional advertising. 


\subsection{Social media marketing}

Marketers are increasingly turning to social media to find and connect with their customers and fans (Berthon et al., 2012). Social media marketing is defined as "the utilization of social media technologies, channels, and software to create, communicate, deliver and exchange offerings that have value for an organization's stakeholders" (Tuten \& Solomon, 2015, p. 21). Social media marketing involves harnessing the interactive and networking capabilities social media channels for marketing purposes (Pereira, de Fátima Salgueiro, \& Mateus, 2014).

Social media marketing creates an unprecedented scale to reach a large number of people, interact with them and leverage their voices for greater marketing impact (Lipsman et al., 2012; Pereira et al., 2014). A purposive application of social media enable marketers to manage customer relationships, promote their brands, educate and entertain customers and influence their purchase decisions (Mangold \& Faulds, 2009). On social media, marketers reach not only existing customers and fans but also their networked friends and contacts, creating a significant multiplier or virality effect (Berthon et al., 2012; Peters et al., 2013). Social media marketing is also instrumental in integrating traditional marketing mix elements (e.g. advertising, sales promotion) with new and engaging tools, such as contests, events, entertainment, and more personalized content (Malthouse, Haenlein, Skiera, Wege, \& Zhang, 2013; Mangold \& Faulds, 2009).

These new and exciting possibilities to connect with customers and fans notwithstanding, social media marketing presents critical challenges for marketers (Berthon et al., 2012). Of particular concern is marketers' loss of control over their brand narrative. As Gensler, Völckner, Liu-Thompkins, and Wiertz (2013) aptly noted,

... with the advent of social media, brand managers have lost their pivotal role as authors of their brands' stories [...] Instead, consumers who are now empowered to share their brand stories easily and widely through social networks have gained a more important voice. (p. 243)

With consumers' growing autonomy and power to create, modify and share user-generated content, marketers' ability to control and coordinate their brand messages has been severely eroded (Berthon et al., 2012).

Social media has redefined the role of consumers, transforming them from passive recipients of brand information to active co-creators of brand meaning and experiences (Muntinga, Moorman, \& Smit, 2011). On social media, consumers exchange brand-related information, share and evaluate their perception and experience of the brand, and create their own branded content (Davis, Piven, \& Breazeale, 2014; Smith, Fischer, \& Yongjian, 2012). Although this growing consumer empowerment can drive positive viral effect for the brand, it can equally precipitate negative word of mouth (Gensler et al., 2013). Indeed, negative word of mouth on social media can seriously hamper the brand because of consumers' tendency to trust user-generated content more than they trust brand-generated content, and the speed with which such information can spread itself (Berthon et al., 2012; Gensler et al., 2013).

Therefore, the challenge for marketers is to develop strategies that exploit the upside of social media marketing, while limiting its downsides (Berthon et al., 2012). A key priority in this regard would be to understand the tools and approaches they can capitalize on to implement an effective social media presence, an issue to which we turn next.

\subsection{Brand pages and brand posts}

One of the most influential, organic and meaningful ways through which brands implement social media marketing is brand pages (Lipsman et al., 2012). Brand pages represent a dedicated and interactive platform established by brands on social media for the purpose of customer interaction and brand communication (Tafesse, 2015). Brand pages allow brands to build an active online community and cultivate direct, personalized and regular interaction with them (Ashley \& Tuten, 2015; Kim, Spiller, \& Hettche, 2015). 
Brand pages are constituted by a community of consumers, customers, brand fans, influencers, employees and other stakeholders who voluntarily subscribe to the brand's updates (Pereira et al., 2014; Zaglia, 2013). Consumers who like/follow a brand page expose themselves not only to the focal brand's regular communications but also to other consumers' comments, reactions and fan posts. Brand pages afford multiple interactivity tools (e.g. like, comment, share, leaving private and public messages on brand pages, etc.), which empower consumers to voice their opinions, express their feelings and share their personal experiences of the brand. These extended opportunities for real-time user interactivity create a lively environment to co-create rich brand experiences (Tafesse, 2016; Zaglia, 2013).

At the heart of brand pages is brand posts, which represent a relatively frequent, concise and unpaid for ${ }^{1}$ updates authored by brands and sent out to customers and fans on a daily basis. Customers and fans receive these brand updates directly in their newsfeed or when they visit the specific brand

Table 1. Brand post categorization approaches

\begin{tabular}{|c|c|c|c|}
\hline Authors & Sample characteristics & Number of brand posts & Categorization approaches \\
\hline de Vries et al. (2012) & 11 international brands & Facebook brand posts $(n=355)$ & Vividness, interactivity, information and entertainment \\
\hline Gummerus et al. (2012) & $\begin{array}{l}\text { A survey of members of a } \\
\text { Facebook gaming commu- } \\
\text { nity }(n=289)\end{array}$ & N/A & Social, entertainment and economic \\
\hline Jahn and Kunz (2012) & $\begin{array}{l}\text { A survey of fans of Facebook } \\
\text { brand pages }(n=523)\end{array}$ & $\begin{array}{l}\text { A netnographic analysis of user-gen- } \\
\text { erated content on Facebook brand } \\
\text { pages belonging to three automotive } \\
\text { brands }(n=661) \text { covering } 52 \text {-weeks }\end{array}$ & $\begin{array}{l}\text { Functional value, hedonic value, social interaction value, } \\
\text { brand interaction value and self-concept value }\end{array}$ \\
\hline $\begin{array}{l}\text { Cvijikj and Michahelles } \\
\text { (2013) }\end{array}$ & $\begin{array}{l}100 \text { FMCG brands selected } \\
\text { from Fan Page List website }\end{array}$ & $\begin{array}{l}\text { Facebook brand posts }(n=5,035) \\
\text { covering eight weeks }\end{array}$ & $\begin{array}{l}\text { Vividness, interactivity, entertainment, information and } \\
\text { remuneration }\end{array}$ \\
\hline Shen and Bissell (2013) & Six beauty brands & $\begin{array}{l}\text { Facebook brand posts covering } \\
\text { eighteen weeks }\end{array}$ & $\begin{array}{l}\text { Event, product (e.g. product launch, product reviews and } \\
\text { tips); promotion (e.g. coupon, sample and giveaways); } \\
\text { entertainment (e.g. beauty poll, Q\&A, survey, activity with } \\
\text { reward and applications) }\end{array}$ \\
\hline Davis et al. (2014) & $\begin{array}{l}\text { In-depth interview and focus } \\
\text { group discussion with } 23 \\
\text { Facebook and Twitter users }\end{array}$ & $\mathrm{N} / \mathrm{A}$ & $\begin{array}{l}\text { Functional brand consumption, emotional brand } \\
\text { consumption, self-oriented brand consumption, social } \\
\text { brand consumption and relational brand consumption }\end{array}$ \\
\hline $\begin{array}{l}\text { De Vries and Carlson } \\
\text { (2014) }\end{array}$ & $\begin{array}{l}\text { A survey of } 404 \text { Facebook } \\
\text { users (students) }\end{array}$ & N/A & $\begin{array}{l}\text { Functional value, hedonic value, social value and } \\
\text { co-creation value }\end{array}$ \\
\hline $\begin{array}{l}\text { Sabate, Berbegal-Mira- } \\
\text { bent, Cañabate, and } \\
\text { Lebherz (2014) }\end{array}$ & Five Spanish travel agencies & $\begin{array}{l}\text { Facebook brand posts }(n=164) \\
\text { covering four weeks }\end{array}$ & Links, images and videos \\
\hline Swani et al. (2014) & $\begin{array}{l}289 \text { companies from the } \\
\text { Fortune } 500 \text { list }\end{array}$ & $\begin{array}{l}\text { Brand tweets }(n=7,097) \text { covering two } \\
\text { weeks }\end{array}$ & $\begin{array}{l}\text { Corporate brand name, product brand name, functional, } \\
\text { emotional, direct calls to purchase, information search } \\
\text { and hashtags }\end{array}$ \\
\hline Ashley and Tuten (2015) & $\begin{array}{l}28 \text { brands from Interbrand's } \\
\text { Best Global Brands }\end{array}$ & $\begin{array}{l}\text { Branded content on Facebook, Twitter, } \\
\text { Myspace, blogs and forums covering } \\
\text { one week }\end{array}$ & $\begin{array}{l}\text { Functional, resonance, experiential, emotional, unique } \\
\text { selling proposition, social cause, exclusivity, animation, } \\
\text { comparative appeal, spokespeople and spokescharacter }\end{array}$ \\
\hline Kim et al. (2015) & $\begin{array}{l}92 \text { brands from Interbrand's } \\
\text { Best Global Brands }\end{array}$ & $\begin{array}{l}\text { Facebook brand posts }(n=1086) \\
\text { covering four weeks }\end{array}$ & $\begin{array}{l}\text { Task-oriented (e.g. brand advertising, new product/service } \\
\text { announcement and online coupons); interaction-oriented } \\
\text { (image, personal statement, special days, talks about } \\
\text { weather/season and entertainment); self-oriented (e.g. } \\
\text { company information, brand event and employee } \\
\text { mentions). }\end{array}$ \\
\hline Tafesse (2015) & $\begin{array}{l}\text { Five top selling automotive } \\
\text { brands in the UK }\end{array}$ & $\begin{array}{l}\text { Facebook brand posts }(n=191) \\
\text { covering four weeks }\end{array}$ & $\begin{array}{l}\text { Vividness, interactivity, brand image, novel content, } \\
\text { transactional, informational and entertainment }\end{array}$ \\
\hline Taecharungroj (2016) & Starbuck's Twitter page & $\begin{array}{l}\text { Brand tweets ( } n=565) \text { covering } \\
52 \text {-weeks, and replies }(n=1392) \\
\text { covering four weeks }\end{array}$ & $\begin{array}{l}\text { Information-sharing (practical tip, product promotion, } \\
\text { store promotion, campaign promotion, official announce- } \\
\text { ment); emotion-evoking content (imagery, sentimental } \\
\text { message, storytelling, inspirational quotation, poem, } \\
\text { humor); action-inducing content (instore download, } \\
\text { events, question, sales promotion, social media } \\
\text { engagement, card registration) }\end{array}$ \\
\hline
\end{tabular}


pages to which they are subscribed (Lipsman et al., 2012). Brand posts are recurrent updates that enable brands to maintain a regular presence on social media (Ashley \& Tuten, 2015). Brand posts strengthen the brand's relationship with customers by providing a theme for ongoing conversations (Gensler et al., 2013). Because brand posts support multiple media types (e.g. text, photo, video, website links), they are capable of communicating a variety of brand meaning and experiences (Tafesse, 2016). Among others, brand posts can be used to build brand awareness, introduce new products, deliver emotional stories, educate customers and stimulate purchases (Kim et al., 2015; Taecharungroj, 2016). Brand posts are equipped with automatic response options, such as like, comment and share. These affordances for instant interactivity allow consumers to express their feelings, opinions and reactions with respect to individual brand posts (Taecharungroj, 2016). In summary, brand posts play a crucial linking role by connecting brands with their customers and fans on a regular basis.

The importance of brand posts notwithstanding, they have rarely been subjected to formalized analyses. An extensive review of the social media literature identifies three ad hoc approaches used to categorize brand posts (see Table 1). The first approach employs crudely specified content domains consisting of entertainment, information and transaction (e.g. Cvijikj \& Michahelles, 2013; de Vries, Gensler, \& Leeflang, 2012). However, this categorization appears ineffective against certain message strategies. For instance, how should brand posts about brand image be categorized-as entertainment or information? How about brand posts about social causes? What of brand community? The second approach considers only a handful of traditional message strategies, such as functional, experiential, emotional, and brand image (e.g. Kim et al., 2015; Swani et al., 2014). An apparent drawback of this approach is its selective emphasis on few message strategies, while ignoring several legitimate ones. The third approach attempts to organize brand posts around consumers' perceived schema, such as social, functional, hedonic and self-concept categories (e.g. Davis et al., 2014; Gummerus, Liljander, Weman, \& Pihlström, 2012; Jahn \& Kunz, 2012). Unlike the other two approaches, this last approach is interested in the subjective meaning that consumers ascribe to brand posts. As such, this approach cannot be relied upon to categorize brand posts according to their intended meaning. Overall, available analyses of brand posts appear to be too ad hoc to offer a systematic framework for categorizing brand posts. To help fill this gap, the present study undertakes a formalized analysis of brand posts and categorizes them into a generalized typology.

\section{Methodology}

\subsection{Sampling decisions}

Researchers studying a social media phenomenon face at least three critical sampling decisions. First, they must select a specific social media channel as their empirical setting. With the constant proliferation of new social media channels and the ubiquity of brand pages across these channels, this decision has never been trickier. In this study, Facebook was selected to offer the primary empirical setting on account of its unparalleled popularity, in turn affording an opportunity to generate broadly applicable insights (Pereira et al., 2014).

The second sampling decision concerns how to generate a workable sample of brand pages. In this study, two independent samples were assembled, one to derive and pretest initial coding categories and another to validate them. To derive and pretest initial coding categories, a purposive sample of brand pages was assembled $(n=20)$. These brand pages, and the brands to which they belong, represent a rich diversity of market contexts (see Table 2). As could be seen, most of the brands in this sample are large, corporate brands that represent various industries and cultural contexts. Such a diverse set of brands enhances our chances of discovering different types of brand posts. To validate the initial coding categories, a probabilistic sample of brand pages were derived from InterBrand's Best Global Brands $2014(n=15)$. InterBrand's Best Global Brands is an annual brand ranking that features top performing global brands from various industries. Brand rankings offer a population of corporate brand pages from which a transparent sample could be generated (Swani et al., 2014). 
Table 2. Characteristics of sample brand pages

\begin{tabular}{|c|c|c|c|c|c|}
\hline \multicolumn{3}{|l|}{ Initial sample } & \multicolumn{3}{|c|}{ Validation sample } \\
\hline Brand page & Industry & $\begin{array}{l}\text { No. of brand } \\
\text { posts }\end{array}$ & Brand page & Industry & $\begin{array}{c}\text { No. of brand } \\
\text { posts }\end{array}$ \\
\hline Tesco & Retail & 18 & Google & Technology & 21 \\
\hline Mitsubishi & Automotive & 17 & Coca Cola & Beverage & 12 \\
\hline Shell & Energy & 15 & IBM & Business services & 13 \\
\hline Pizza Hut & Restaurant & 23 & Microsoft & Technology & 16 \\
\hline GAP & Apparel & 20 & GE & Diversified & 25 \\
\hline$H \& M$ & Apparel & 22 & Samsung & Technology & 14 \\
\hline L'Oréal Paris & FMCG & 19 & Toyota & Automotive & 14 \\
\hline Norwegian & Airlines & 17 & McDonalds & Restaurant & 13 \\
\hline Hyundai & Automotive & 16 & Mercedes Benz & Automotive & 17 \\
\hline Starbucks & Restaurant & 16 & BMW & Automotive & 17 \\
\hline Estee Lauder & FMCG & 13 & Intel & Technology & 23 \\
\hline Chivas Regal & Spirit & 11 & Disney & Media & 13 \\
\hline $\begin{array}{l}\text { Sheraton Hotels } \\
\text { and Resorts }\end{array}$ & Hotel & 11 & Cisco & Technology & 18 \\
\hline Adidas & Sporting Goods & 16 & Amazon & Retail & 22 \\
\hline Nissan & Automotive & 47 & Oracle & Technology & 11 \\
\hline Burger King & Restaurant & 23 & & & \\
\hline American Express & Financial services & 17 & & & \\
\hline Siemens & Technology & 27 & & & \\
\hline Total & & 371 & Total & & 249 \\
\hline
\end{tabular}

Note: Apple, which does not have an official brand page on Facebook, is replaced by the 16th ranked brand on InterBrands Best Global Brands 2014: Oracle.

The third sampling decision concerns how many brand posts to analyze from each brand page. This decision, not unlike other sampling decisions, must balance the need for generality with the cost of data collection. Consistent with current practices in the literature, brand posts covering a four-week period were analyzed for both samples (1-31 May 2015). In a social media environment, a four-week window is long enough for a rich variety of brand posts to be published (Ashley \& Tuten, 2015). Summing up, two independent samples were assembled for subsequent analyses: a purposive sample of brand posts $(n=371)$ from which initial brand post categories were derived; and a probabilistic sample of brand posts $(n=249)$ on which the initial brand post categories were validated using a double-coding procedure.

\subsection{Coding procedure}

Our coding procedure draws on qualitative content analysis, which entails "the subjective interpretation of the content of text data through the systematic classification process of coding and identifying themes and patterns" (Hsieh \& Shannon, 2005, p. 1278). Qualitative content analysis extracts manifest and latent meanings following a systematic and transparent procedure for analyzing data (Zhang \& Wildemuth, 2009).

Broadly speaking, qualitative content analysis begins by defining the unit of analysis, which captures the basic unit of data to be analyzed and coded (Elo \& Kyngäs, 2008). Sentences, paragraphs, full text documents or entire interview protocols might serve as unit of analysis (Graneheim \& Lundman, 2004). In our case, individual brand posts, and all the ancillary information they incorporate (i.e. texts, photos, videos and links), captured the unit of analysis. 
The second step involves reviewing the relevant literature to identify pre-existing coding categories. Referred to as deductive coding, this approach is applied when prior literature exists, but is incomplete and would benefit from further analysis (Hsieh \& Shannon, 2005). In accordance, two of the authors involved in this study reviewed the advertising and the social media literature to identify pre-existing (initial) coding categories for brand posts. This review was especially focused on the advertising message strategy literature and recent analyses of brand posts in the social media literature. From these literature sources, 18 initial coding categories were generated (see Table 3).

\section{Table 3. Coding procedure, frequency and reliability statistics}

\begin{tabular}{|c|c|c|c|c|c|c|}
\hline \multicolumn{2}{|c|}{ Initial coding categories } & \multirow{2}{*}{$\begin{array}{l}\text { Final coding } \\
\text { categories }\end{array}$} & \multirow{2}{*}{$\begin{array}{c}\text { No. of } \\
\text { observation }\end{array}$} & \multirow[t]{2}{*}{$\%$ of observation } & \multicolumn{2}{|c|}{ Inter-coder reliability } \\
\hline $\begin{array}{l}\text { Deductive } \\
\text { codes }\end{array}$ & Inductive codes & & & & $I_{r}$ & $\%$ agreement \\
\hline Emotive language & - & \multirow{3}{*}{$\begin{array}{l}\text { Emotional brand } \\
\text { posts }\end{array}$} & \multirow[t]{3}{*}{81} & \multirow[t]{3}{*}{33} & \multirow[t]{3}{*}{0.79} & \multirow[t]{3}{*}{74} \\
\hline $\begin{array}{l}\text { Emotional story } \\
\text { telling }\end{array}$ & - & & & & & \\
\hline Humor, jokes & - & & & & & \\
\hline $\begin{array}{l}\text { Product and service } \\
\text { attributes, benefits }\end{array}$ & - & \multirow[t]{3}{*}{$\begin{array}{l}\text { Functional brand } \\
\text { posts }\end{array}$} & \multirow[t]{3}{*}{76} & \multirow[t]{3}{*}{31} & \multirow[t]{3}{*}{0.82} & \multirow[t]{3}{*}{82} \\
\hline $\begin{array}{l}\text { External recogni- } \\
\text { tions, quality } \\
\text { awards }\end{array}$ & - & & & & & \\
\hline $\begin{array}{l}\text { Green product } \\
\text { claims }\end{array}$ & - & & & & & \\
\hline- & Educational & $\begin{array}{l}\text { Educational brand } \\
\text { posts }\end{array}$ & 74 & 30 & 0.91 & 90 \\
\hline Brand image & - & \multirow[t]{4}{*}{ Brand resonance } & \multirow[t]{4}{*}{66} & \multirow[t]{4}{*}{27} & \multirow[t]{4}{*}{0.83} & \multirow[t]{4}{*}{85} \\
\hline Celebrity appeal & - & & & & & \\
\hline- & Branded products & & & & & \\
\hline- & Brand heritage & & & & & \\
\hline Sensory stimulation & - & \multirow{3}{*}{$\begin{array}{l}\text { Experiential brand } \\
\text { posts }\end{array}$} & \multirow[t]{3}{*}{66} & \multirow[t]{3}{*}{27} & \multirow[t]{3}{*}{0.82} & \multirow[t]{3}{*}{84} \\
\hline $\begin{array}{l}\text { Behavioral } \\
\text { stimulation }\end{array}$ & - & & & & & \\
\hline Brand events & - & & & & & \\
\hline- & Current event & Current event & 46 & 19 & 0.83 & 91 \\
\hline- & Personal & $\begin{array}{l}\text { Personal brand } \\
\text { posts }\end{array}$ & 36 & 15 & 0.83 & 92 \\
\hline- & Employee & $\begin{array}{l}\text { Employee brand } \\
\text { posts }\end{array}$ & 24 & 10 & 0.91 & 97 \\
\hline- & Brand community & Brand community & 17 & 7 & 0.81 & 96 \\
\hline Customer services & - & \multirow{3}{*}{$\begin{array}{l}\text { Customer } \\
\text { relationship }\end{array}$} & \multirow[t]{3}{*}{14} & \multirow[t]{3}{*}{6} & \multirow[t]{3}{*}{0.81} & \multirow[t]{3}{*}{97} \\
\hline $\begin{array}{l}\text { Customer } \\
\text { testimonial }\end{array}$ & - & & & & & \\
\hline Customer feedback & - & & & & & \\
\hline Social causes & - & $\begin{array}{l}\text { Cause-related } \\
\text { brand posts }\end{array}$ & 14 & 6 & 0.91 & 98 \\
\hline $\begin{array}{l}\text { Price discounts/ } \\
\text { deals }\end{array}$ & - & \multirow[t]{3}{*}{ Sales promotion } & \multirow[t]{3}{*}{13} & 5 & 0.87 & 97 \\
\hline $\begin{array}{l}\text { Promotional } \\
\text { campaigns }\end{array}$ & - & & & & & \\
\hline Competition and & - & & & & & \\
\hline & & Total & 528 & 216 & & \\
\hline
\end{tabular}

Note: Total observation of message strategy exceeds total number of brand posts $(n=249)$ because most brand posts incorporate two or more message strategies. 
The third step involves deriving fresh coding categories from empirical data. Referred to as inductive coding, this step is applied when the researcher seeks to avoid preconceived categories, instead allowing the categories to flow directly from the data (Hsieh \& Shannon, 2005). This procedure was applied on the initial sample of brand posts $(n=371)$, where the two authors carefully studied all the information comprised in the brand posts to infer the main messages being communicated. Keywords, themes and ideas that seemed to characterize the brand posts were highlighted and discussed. When the main messages corresponded to one or more of the deductive coding categories, the brand posts would be coded accordingly. When this was not the case, new categories would be proposed inductively. Using this approach, seven initial coding categories were generated (see Table 3). As coding proceeded and more information became available, the initial coding categories were revised for greater conceptual clarity. In the interest of parsimony, the 25 initial coding categories were reduced to a final 12 by combining complementary coding categories. At this point, an indepth coding manual was prepared to facilitate the double-coding of the validation sample.

In the final step, the two authors double coded the validation sample of brand posts $(n=249)$. As recommended, the two authors did not communicate during this stage and made their coding decisions independently (Kolbe \& Burnett, 1991). Once the validation-coding was finalized, inter-coder reliability coefficients were calculated using Perreault and Leigh's (1989) $I_{r}{ }^{2}$ which is a more conservative inter-coder reliability coefficient than percent agreement. As reported in Table 3 , the two coders achieved quite robust agreement levels $\left(I_{r}>0.8\right)$. Percent agreement is reported for the purpose of baseline reference. Disagreements were resolved through consensus.

\section{A proposed categorization of brand posts}

By implementing a systematic coding procedure, we derived 12 categories of brand posts. Table 4 summarizes the definition and common message themes of the proposed categories. In this section, we discuss these categories in greater detail drawing on representative examples from the empirical data ${ }^{3}$ and theoretical insights from the relevant literature. We discuss the brand post categories in their order of popularity in the validation sample.

Table 4. Summary of the proposed categories of brand posts

\begin{tabular}{l|l} 
Proposed categories & Definition and common message themes \\
\hline Emotional brand posts & $\begin{array}{l}\text { These brand posts evoke consumers' emotions. To this end, the posts typically employ } \\
\text { emotion-laden language, inspiring stories or humor and jokes to arouse affective } \\
\text { responses, such as fun, excitement and wonder }\end{array}$ \\
\cline { 2 - 3 } Functional brand posts & $\begin{array}{l}\text { These brand posts highlight the functional attributes of company products and } \\
\text { services. Typically, these posts promote the benefits of company products and services } \\
\text { according to performance, quality, affordability, design and style criteria }\end{array}$ \\
\cline { 2 - 3 } Educational brand posts & $\begin{array}{l}\text { Common themes: product functional claims, product reviews, awards, green } \\
\text { credentials, and so forth }\end{array}$ \\
\hline & $\begin{array}{l}\text { These brand posts educate and inform consumers. These posts help consumers } \\
\text { acquire new skills on proper ways of applying products, or discover new information } \\
\text { about broader industry trends and developments }\end{array}$ \\
\cline { 2 - 3 } & $\begin{array}{l}\text { Common themes: do it yourself tips, instructions, blog posts, external articles, } \\
\text { technical interviews with employees, and so forth }\end{array}$ \\
\hline \multirow{2}{*}{ Brand resonance } & $\begin{array}{l}\text { These brand posts direct attention to the brand promise and identity of the focal } \\
\text { brand. These posts highlight some of the main tropes of brand identity, such as brand } \\
\text { image, brand personality, brand association and branded products with the goal of } \\
\text { differentiating the brand and favorably influencing consumers' brand attitude and } \\
\text { association }\end{array}$ \\
\hline $\begin{array}{l}\text { Common themes: brand image (i.e. brand logo, brand slogan, brand character, etc.), } \\
\text { photos of branded products, celebrity association, and brand history }\end{array}$ \\
\hline
\end{tabular}

(Continued) 
Table 4. (Continued)

Proposed categories

Experiential brand posts

Current event

Personal brand posts

Con

Employee brand posts

Brand community

Customer relationship

\section{Definition and common message themes}

These brand posts evoke consumers' sensory and behavioral responses. Experiential brand posts highlight the sensory and embodied qualities of the brand and often associate the brand with pleasurable consumer experiences

Common themes: sensory stimulation (i.e. visual, auditory, taste, odor, etc.), physical stimulation (i.e. physical actions, performances, activities, etc.), brand events (product launches, festivals, fan events, sponsored events, etc.)

These brand posts comment on themes that capture active talking points in the target audience, such as cultural events, holidays, anniversaries, and the weather/season. These brand posts initiate conversations with consumers using timely and widely talked about events

Common themes: weather, cultural events (i.e. sport, film, TV shows), holiday, special day and anniversaries

These brand posts center around consumers' personal relationships, preferences and/ or experiences. These brand posts typically invoke personally meaningful themes, such as family, friendship, personal anecdotes or future plans to initiate deeply personal conversations with consumers

Common themes: friends, family, personal preferences, anecdotes and future plans

These are brand posts about employees. Employee brand posts present employees' perspective on a range of issues, such as employees' technical expertise, their managerial philosophies, or their personal interests, hobbies and worldviews

These brand posts promote and reinforce the brand's online community. These brand posts foster a sense of community identification and engagement with the community, by recruiting new community members, as well as encouraging participation from existing members

Common themes: encouraging fans to become members of the brand's online community, acknowledging fans (e.g. mentioning their name, tagging them), using/ soliciting user-generated content

These brand posts solicit information and feedback about customers' needs, expectations and experiences. These brand posts seek to deepen the impact of customer relationships in social media channels by encouraging customer feedback, reviews and testimonies

Common themes: customer feedback, customer testimony and customer reviews and customer services

These brand posts highlight socially responsive programs supported by the focal brand. These brand posts promote worthy social causes and initiatives and encourage customers and fans to support them

These are brand posts that entice consumers to take actions toward a buying decision. These brand posts often contain transactional details such as price and availability points, as well as concrete promotional offers, such as price discounts, coupons and competitions

Common themes: price discounts, coupons, free samples, customer contests and product competitions

\subsection{Emotional brand posts}

Emotional brand posts are brand posts that are intended to evoke consumers' emotions. Emotional brand posts employ emotion-laden language, inspiring stories or humor and trivia to derive affective responses from consumers. The main thrust of emotional brand posts is to depict the focal brand in emotional terms, such that the brand can establish emotional connection with consumers. The emotional brand post category accounts for $33 \%$ of the brand posts in the validation sample, and comes in three major variants.

The first variant employs emotion-laden language. This variant typically uses emotionally expressive words and symbols. Among frequently evoked emotions are love, fun, awe, and celebration. An example is a video brand post by Disney (May 26), showing a behind-the-scene footage from a rendition of one of its musicals. The text at top of the video reads, "It's crystal clear that Aladdin-The 
Musical's rendition of 'A Whole New World' is shining, shimmering, splendid." Shining, shimmering and splendid are deeply emotive words that can arouse a sense of excitement among viewers. Another example is a recipe video by Amazon from May 5, prefaced by "Its Monday, and you deserve a moment to relax. Use this recipe to chill out or fire up your Cindo de Mayo celebration a little early." References to "a moment to relax", "chill out", "fire up" and "celebration" make this brand post emotionally resonant.

The second variant employs emotional storytelling. This variant typically employs longer form videos or blog posts to tell inspiring or moving stories. The stories often highlight customers, fans, employees, or other personalities and entities outside the company who seemed to have succeeded under unlikely circumstances. An instance of this strategy is a brand post by Oracle from May 21:

Meet Isabella, senior technical support engineer, founder of Shining Star Orphanage in Kenya, and passionate volunteer who has a love for helping people improve their lives.

The attached link redirects to a YouTube video, where Isabella discusses her humble upbringing in rural Kenya, how she came to join Oracle and the orphanage center that she founded. Another example is a video brand post by Coca-Cola from May 25. With the patriotic song, "America the beautiful," playing in the background, the video depicts a diverse group of Americans engaged in archetypal American pastimes-a cowboy riding a horse in the wilderness, kids watching movies in cinema halls, teens skateboarding in the street, and families enjoying dinner together. The text at the top reads, "Today we honor the heroes who have sacrificed so much, for a country born of so many. \#AmericaIsBeautiful”.

The third variant employs humor and trivia. This variant portrays the soft side of the brand by using everyday jokes and trivia. A good example can be found from Intel, where Jim Parsons is featured in a series of short, humorous videos to promote Intel's new processing chips. Jim Parsons plays the socially awkward physicist Dr. Sheldon Cooper in The Big Bang Theory. In one Intel ad clip from May 22, Jim Parsons engaged in a heated exchange with an airport security personnel who was instructing another traveler passing through security checks “you can't put two [laptop and tablet] in one [airport tray]!" Parsons interjects to remind her that, "At Intel, they make technology that lets a device be a laptop and a tablet. So, you can put two in one!" An example of an emotional brand post employing trivia is a time-lapse video by HP. The six-second video from May 27 shows the making of a paper plane bearing HP's brand logo. The text at the top of the video reads, "Ladies and gentlemen, enjoy the flight. Happy National Paper Airplane Day!"

To summarize, emotional brand posts employ emotion-laden language, inspiring stories or humor and trivia to trigger affective responses among consumers. Emotional brand posts cause stronger feelings and emotions, enabling the brand to connect with consumers on an emotional level (Davis et al., 2014). The fact that emotional brand posts can be seamlessly combined with other message strategies explains their widespread popularity. For instance, many of the emotional brand posts cited above possess extra message cues including functional, educational and brand image.

\subsection{Functional brand posts}

Functional brand posts are brand posts that highlight the functional attributes of products and services. Functional brand posts typically promote the benefits of company products and services according to performance, quality, affordability, efficiency and style criteria. Frequently also, functional brand posts comment on product specifications and technical features. Functional brand posts represent a useful category to convey in-depth product information and help consumers to make informed purchase decisions. The functional brand post category accounts for $31 \%$ of the brand posts in the validation sample, and comes in two major variants.

The first variant captures product attributes and benefits as claimed by the brand itself. This variant disproportionately targets new products and services, perhaps because of consumers' relatively 
limited exposure to such products and services. A typical example is a brand post by HP from May 10: "Who knows a machine this slim could store so much? The all new Pavilion $\times 360$." The text is accompanied by a photo that accentuates Pavilion $\times 360$ 's slim design, while the attached link redirects to a dedicated product page where consumers can learn additional details about the new laptop. Another example is a brand post by Google (May 28): "Introducing Google Photos. Organize and store unlimited, high-quality photos and videos." The attached link redirects users to a dedicated Google Photos page, where they can learn additional details about the service and sign up to it.

The second variant promotes product attributes and benefits as claimed by external reviewers. This variant offers a comprehensive coverage of products and services based on expert reviews, which likely enjoys greater credibility among consumers due to favorable source effects. This strategy is particularly popular among automotive brands, where they share detailed product reviews by third party specialists. An instance of this occurred on May 27 when Mercedes Benz shared a review article by The Washington Post. The article offers an in-depth review of the GLA 45 AMG, detailing its design elements, features, performance, price, and even the typical buyer profile of the car.

Overall, the functional brand post category offers consumers with detailed product and service information. By highlighting core product and service features, this category can help consumers make informed purchase decisions (Puto \& Wells, 1984; Taylor, 1999). With its emphasis on new products and solutions, the functional brand post category can also satisfy consumers' noveltyseeking behavior (Tafesse, 2015). However, there is also a risk that functional brand posts can be viewed as mere sales pitches due to their emphasis on company products and services, in turn diminishing their ability to create stronger consumer engagement.

\subsection{Educational brand posts}

Educational brand posts are brand posts that seek to educate and inform consumers on a variety of topics. The main purpose of educational brand posts is to help consumers acquire new skills about product and service applications, or learn about substantive issues involving broader industry developments. The topical interest of educational brand posts can be quite broad at times, covering issues that have little to do with company products and services. Derived inductively from the data, this brand post category accounts for $30 \%$ of the brand posts in the validation sample, and comes in two major variants.

The first variant is focused on hands-on, everyday product applications. Typically, this variant draws on professional tips and instructions to educate consumers on the proper methods of applying company products and services. Although several brands employ this variant, we found Amazon to be a rather avid user. Amazon publishes a series of short, professionally produced, do-it-yourself videos covering a wide range of topics, in which product items available on Amazon.com are heavily featured. On May 15, for instance, the brand published an instructional video about adding architectural details to a living room, while on May 27 it published another video about doing vertical gardening in a small space.

The second variant deals with more generic topics that do not seem to have immediate connections with company products and services. This variant is primarily employed by technology and B2B service brands, and draws heavily on articles, opinion pieces and commentaries published elsewhere in online news sites and specialist blogs. For instance, on May 11, IBM shared a link to a Forbes article on the emerging phenomenon of smart stadiums. The article discusses how “... organizers of major sporting events and owners of sporting venues are turning to new cloud, mobile and analytics technologies to deliver great fan experience ....". Among other avid users of this strategy are Intel, Microsoft and Cisco.

To generalize, the educational brand post category informs and educates consumers on a range of issues. Some of these issues are focused on hands-on, everyday product applications, while others are focused on broader industry trends and developments. The ultimate thrust of educational brand 
posts appears to be empowering consumers to solve product-related problems or find creative ways of applying them in their daily lives (Tafesse, 2016). Educational brand posts provide consumers with ample intellectual stimulation by furnishing extended commentaries and articles on various topics.

\subsection{Brand resonance}

Brand resonance posts are brand posts that direct attention to the brand promise and identity of the focal brand. These posts highlight some of the main tropes of brand identity, such as brand image, brand personality, brand association and/or branded products. Brand resonance posts seek to differentiate and favorably position the focal brand in the minds of consumers. The brand resonance category accounts for $27 \%$ of the brand posts in the validation sample, and comes in four major variants.

The first variant is focused on brand image. This variant prominently features elements from the brand's visual identity, such as brand logo, brand slogan and brand character. Brands employ these elements to reinforce their image and favorably position themselves in the minds' of consumers. Coca Cola, Google and McDonald's are among the frontrunners in applying this strategy. For instance, Coca Cola extended its "Share a Coke" campaign to Facebook, which saw its brand logo replaced by popular (fans') names. The brand then leveraged this theme to create a series of interactive and personalized brand posts. On May 1, the brand posted: "\#ShareaCoke is back with 1,000 names! Step right up and try to pause this video when you see yours." The accompanying video shows a spinning coke bottle with several common names written on it. Likewise, Google frequently reinterprets its brand logo to mark important events. An instance of this occurred on May 10 when the brand posted a photo of its brand logo with the second "o" replaced by an image of a hen and a chick. The text at the top reads, "Happy Mother's Day from every cub, chick, pup, joey and kid!" Similarly, McDonald's resurrected its brand character-the Hamburglar-from a 13-year hiatus, and featured it in a series of brand posts to promote its newly launched menu item. Fans were excited about Hamburglar's comeback and took particular interest in his revamped appearance, allowing McDonald's to cultivate meaningful interaction with customers and fans, while also promoting its new menu item.

The second variant displays photos of branded products. Used most frequently by automotive and electronics brands, this variant typically employs a clean and visually striking image of branded products. In an attempt to captivate fans with the enticing product visuals, the brand posts often avoid adding complex ancillary information, such as lengthy texts or website links. An example is a brand post from May 30, where BMW posted a close-up photo of the front end of one of its cars. The minimalist text at the top reads, "In the wild. \#BMW \#X6 M."

The third variant involves brand posts featuring celebrities and influencers. The use of celebrities in marketing to reinforce brand personality and create positive brand associations is widespread. A video brand post by Mercedes Benz featuring tennis star Roger Federer is a good example for this. In the video, Roger Federer is seen driving the $2016 \mathrm{GLE}$, while an off-camera voice narrates:

If you have been at the top of your game for so long, how do you stay there? How do you keep setting a bar that you alone have raised? You do it by continuing what got you there in the first place. A commitment to be the very best ...

The fourth variant involves brand posts celebrating brand heritage. This variant asserts the historical contribution and accomplishment of the focal brand. An example is a photo brand post by IBM (May 21): "From the archives: IBMer Werner Buchholz, who coined the term 'byte', in front of the IBM Stretch computer, which he helped design. \#TBT." Another example is a brand post by BMW (May 23): "A vision of athleticism grounded in the past-introducing the \#BMW 3.0 CSL Hommage." Accompanying the text is a photo of two identical BMW 3.0 CLSs parked side by side, except that one is new and the other is old. 
To conclude, brand resonance posts are crucial to project and reaffirm the brand promise and identity of the focal brand. Brand resonance posts seek to imprint positive brand imageries and associations (Puto \& Wells, 1984). These brand posts are as such useful to position the focal brand favorably in the minds of consumers (Laskey et al., 1989). Brand resonance posts take on added significance on social media, however, as consumers' commonly use brands to construct and project their self-identity online (Vernuccio, Pagani, Barbarossa, \& Pastore, 2015; Wallace, Buil, \& Chernatony, 2014). As such, brand resonance posts could constitute an attractive proposition for consumers looking to express their idealized self-image using their preferred brands.

\subsection{Experiential brand posts}

Experiential brand posts evoke consumers' sensory and behavioral responses using relevant brand cues. The specific responses evoked by experiential brand posts can be either sensory, such as visual, auditory and gustatory, or behavioral, such as physical actions and embodied performances. Experiential brand posts accentuate the sensory and embodied qualities of the focal brand by linking the brand with pleasurable consumer experiences. The experiential brand post category accounts for $27 \%$ of the brand posts in the validation sample, and comes in three major variants.

The first variant employs sensory brand cues. Depending on the focal brands' area of specialization, this variant could employ visual, auditory, gustatory or olfactory brand cues. For instance, restaurant and beverage brands frequently employ gustatory brand cues to magnify the taste effects of their menu items. The following brand post by McDonald's from May 11 is a good example of this approach:

Your eyes aren't deceiving you. Tasty, juicy Sirloin Third Pound Burgers have brought the Hamburglar back into action. Bite into one before he does-they won't last long!

The text is accompanied by a photo of McDonald's brand character - the Hamburglar - grabbing a Sirloin Third Pound Burger on his hands. Others, including electronics and automotive brands, frequently employ visual and auditory brand cues to draw attention to the sensory prowess of their products. An example is a brand post by Samsung from May 25: "4 K SUHD TV lets you escape further. Say \#hellocolor and see the more brilliant blues of your favorite coasts." Accompanying the text is a panoramic photo of the blue and white houses of the Cyclades islands as projected through a $4 \mathrm{~K}$ SUHD screen.

The second variant of experiential brand posts draws attention to embodied actions. This variant employs behavioral brand cues, such as physical actions, bodily performances or sports activities, to amplify the physical qualities of the focal brand. These brand posts portray the brand as an enabler and integral part of adventurous and thrilling consumer experiences. An instance of this strategy is a brand post by Toyota from May 18: "Your \#4Runner is the archenemy of apathy. \#KeepItWild \#4Runner." The accompanying video shows the Toyota Four Runner riding on a dirt road with scenes of extreme water rafting and mountain skiing weaved into the video.

The third variant of experiential brand posts employs brand events. Brand events such as sponsored events, product launches and live events provide consumers with a direct, experiential access to the brand. Some of these brand posts promote upcoming events, as does BMW on May 1: "Follow the action live this Sunday, 5/3, at 4 pm ET as BMW USA Motorsport takes on the TUDOR United SportsCar Championship ... at Mazda Raceway Laguna Seca." The attached link redirects the user to a YouTube channel, where they can stream the event directly. Other brand posts report on past events, often using a photo gallery or an extended video footage. An example is a brand post by Mercedes Benz from May 18:

As the weather heats up, it's time for music festival ... As an official sponsor of Rock in Rio USA, we took a fleet of vehicles to Las Vegas for two weekends of amazing music and unforgettable experiences. Relive the sights and sounds in this gallery. 
Overall, the experiential brand post category accentuates "the moment of pleasure" and the experiential value of the focal brand (Puto \& Wells, 1984; Taylor, 1999). Experiential brand posts employ sensory, embodied and event-based brand cues to render the brand experientially accessible by linking it to specific consumer experiences. These brand posts portray the brand as a key enabler of delightful consumer experiences. For this reason, experiential brand posts represent a powerful message strategy for brands to orchestrate a rich and authentic brand experience on social media (Tafesse, 2016).

\subsection{Current event}

These brand posts focus on timely themes that capture active talking points among a given population, such as cultural events, holidays, anniversaries, and the weather/season. The goal of current event brand posts is to initiate timely conversations with consumers using widely talked about events. By alluding to themes that capture a staple of everyday conversation, current event brand posts facilitate the brand to get involved - naturally-in ongoing social media conversations. Derived inductively from the data, this brand post category accounts for $19 \%$ of the brand posts in the validation sample, and comes in three major variants.

The first variant captures brand posts about popular cultural events, such as film releases, sports competitions, TV shows, and so forth. This variant makes references to timely and ongoing cultural phenomena to start conversations with consumers. An instance of this can be found from Mercedes Benz (May 19): "Something big is coming June 12th. Check out the GLE Coupe's epic adventures in theaters this summer in \#JurassicWorld." The accompanying trailer from Jurassic World shows glimpses of the new GLE Coupe in action.

The second variant captures brand posts that mark popular holidays, anniversaries and/or special days. This variant takes advantage of widely celebrated days to start a conversation with consumers. An instance of this occurred on May 7 when Google posted: "Mother's Day is right around the corner. Are you ready?" The attached link redirects users to a dedicated Google page, where they can find a range of ideas, tips and suggestions useful for Mother's Day celebration.

The third variant captures brand posts about the weather/season. This variant comments on the weather and the seasons to start a conversation with consumers. An example of this strategy is a brand post by Google from May 1: "Spring is in full bloom and summer is approaching ... must be May Day!" The attached photo shows an image of a maypole captioned with: "Ok Google, what is a maypole?"

To conclude, the current event brand post category facilitates the focal brand to get involved in ongoing social media conversations using timely events and occurrences. Current event brand posts help keep the brand fresh and relevant in a highly dynamic environment and enable the brand to be invited into people's lives and their private conversations (Fournier \& Avery, 2011). The relative popularity of current event brand posts reflects their importance for customer interaction on social media. Brands thus need to monitor ongoing social media conversations and create brand posts that leverage these conversations (Barnes \& Jacobsen, 2014). In this way, brands can establish a basis for a more cordial conversation with consumers.

\subsection{Personal brand posts}

Personal brand posts center around consumers' personal relationships, preferences and/or experiences. These brand posts invoke personally meaningful themes, such as family, friendship, personal anecdotes and/or future plans to initiate deeply personal conversations with consumers. Personal brand posts encourage consumers to express themselves based on their personal opinions, feelings and anecdotes. Derived inductively from the data, this category accounts for $15 \%$ of the brand posts in the validation sample, and comes in two major variants. 
The first variant alludes to consumers' personal relationships. This variant typically invokes family and friendship themes to initiate conversations with consumers. A brand post by Coca-Cola from May 9 is a typical example: "Cheerleader. Hero. BFF. But you simply call her mom. Tell us why she's the best ever and \#ShareaCoke with mom on her special day." The attached video shows a spinning coke bottle with words like "Cheerleader," "Hero," and "Mentor" inscribed on it. Another example is a brand post by Amazon (May 10): "Who doesn't love breakfast in bed? Let the kids help in the kitchen tomorrow morning for an easy breakfast Mom will love." The text is accompanied by a video of a breakfast recipe. In both cases, the respective brands alluded to personal relationships as a means to connect with consumers on a more personal level.

The second variant relates to consumers' anecdotes and preferences. Here, the brand encourages consumers to express their feelings, opinions, plans, everyday anecdotes, and so on. An example is a brand post by Intel (May 13): “Jim's new Intel Core i7 processor has him fully immersed. What's the longest gaming hole you've gotten into?” The attached video clip shows Jim Parsons immersively playing a computer game. A second example is a video brand post by Amazon (May 28): "Find out all you need to know about wine and cheese pairings to make this \#WineWednesday extra fancy! Which pairing is your favorite?" The questions posed at end of these two brand posts encourage consumers to express themselves based on their anecdotes and preferences.

Overall, personal brand posts seek to deepen the brand's involvement in consumers' daily lives by invoking personally meaningful themes. The potential disclosure that arises from personal brand posts, and the conversations that ensue, create an opportunity for the brand and other consumers in the community to know each other better, and reinforce their social relationships. This finding reinforces prior observations in the literature that brands foster a sense of para-social interaction on social media to cultivate a personal-level connection with consumers (Van Noort, Antheunis, \& Verlegh, 2014; Walrave, Poels, Antheunis, Van den Broeck, \& van Noort, 2016).

\subsection{Employee brand posts}

As the name implies, employee brand posts are brand posts about employees. Employee brand posts can span various topics, such as employees' technical expertise, their managerial philosophies, or their personal interests, hobbies and worldviews. Employee brand posts give a voice to employees and empower them to communicate directly with consumers. Particularly popular among technology and B2B service brands, this brand post category accounts for $10 \%$ of the brand posts in the validation sample, and comes in three major variants.

The first variant focuses on employees' opinion on company technology and processes. In this variant, employees often draw on their technical expertise and experiences to explain technically complex issues. An example of this can be found from Intel (May 6): "Intel fabs have the most sophisticated manufacturing process in the world-cutting-edge automated technology that makes innovation, computing and people's lives better." The accompanying video features Intel's Director of Manufacturing IT talking at length about Intel's automated manufacturing process.

The second variant focuses on employees' take on broader corporate issues. This variant typically features senior managers addressing broader organizational issues, such as strategy, corporate culture, partnerships and employee relations. An example is a brand post by Cisco from May 4: "Join \#NewCEO Chuck Robbins as he talks about the transition into his new role and the tremendous opportunity." In the attached video, Cisco's newly appointed CEO addresses a series of questions focused on his strategic priority and the vision he wishes to accomplish at Cisco.

The third variant focuses on employees' personal interests, hobbies, opinions, achievements, and so on. The focus here is on employees' personal stories. An example is a brand post by IBM from May 25: "Two punks ready to roll. Why IBMer Kevin Roche is not your average geek. \#GeekPrideDay." The attached link redirects to an internal blog post recounting the story of an IBM engineer who has a penchant for robotics and his numerous creations and awards over the years. 
To conclude, the employee brand post category presents employees' perspective on a range of issues. By publicizing employees who are traditionally omitted from outbound brand communications, employee brand posts offer customers and fans a direct access to employees. At the heart of these brand posts are employees' personal stories as told through their expertise, interests, opinions and worldviews. Employee brand posts can thus motivate customers and fans to connect with employees on a more personal level, a connection that might eventually extend to the focal brand itself.

\subsection{Brand community}

Brand community brand posts are brand posts aimed at promoting and strengthening the brand's online community. These brand posts seek to recruit new members into the community, thus expanding the brand's community base, as well as promote active participation among existing members, thus intensifying the brand community's vibrancy. The ultimate thrust of community-oriented brand posts appears to be fostering engagement and member identification with the brand community. Derived inductively from the data, this brand post category accounts for $7 \%$ of the brand posts in the validation sample, and comes in two major variants.

The first variant is aimed at recruiting new members to the brand's online community. This variant typically exposes fans to the brand's expanded network of online communities and encourages them to join these 'new' communities. An example of this tactic can be found from BMW (May 16): "Morning run through the desert. Visit BMW USA on Instagram for more exclusive content. \#BMWi8 \#HelloFuture." The text is accompanied by a photo of the BMW i8, while the attached link redirects users to BMW's official page on Instagram-thus, exposing BMW's Facebook fans to BMW's brand community on Instagram.

The second variant is aimed at enhancing community participation. This variant seeks to drive active participation and engagement among existing members by acknowledging them (e.g. mentioning their name, tagging them in brand posts), or by using/soliciting their content (user-generated content). An instance of this strategy can be found from Coca-Cola (May 5): "Show the world how you celebrate diversity by posting a photo of what \#LoveHasNoLabels means to you." This brand post is intended to increase community participation by encouraging fans to contribute user-generated content and get involved in the ongoing conversation on Coca-Cola's brand page.

Overall, brand community posts seek to foster a sense of community identification among consumers by encouraging sharing and participation behaviors. These brand posts can help consumers forge strong social bonds around the focal brand (Tafesse, 2016). However, the paucity of brand community posts in our sample signify marketers' limited ability in, or perhaps impact of, this category of brand posts. This finding is consistent with prior assertions in the literature that brand pages tend to embody a weak from of brand community and that consumers often struggle to develop a strong feeling of belongingness to a brand community (Zaglia, 2013).

\subsection{Customer relationship}

These brand posts highlight issues that underpin customers' relationship with the focal brand, such as customer services, customer testimony and customer feedback, among others. Customer relationship brand posts facilitate opportunities for the brand to solicit and learn about customers' needs and priorities - both current and prospective. These brand posts seek to enrich and deepen the impact of customer relationships by leveraging social media interactivity. The customer relationship brand posts account for $6 \%$ of the brand posts in the validation sample, and come in three major variants.

The first variant is focused on customer services. This variant usually makes common service announcements and reminders. A typical example is a brand post by McDonald's (May 14): "Lunch just got more lovin'. Order from Postmates to have your menu items delivered straight to your desk." The attached link redirects customers to an external website, where they can place their orders. 
The second variant is focused on customer testimonials. This variant typically highlights customer success stories, asserting how customers benefited from their partnership with the company. An example for this can be found from Microsoft (May 4): "Real Madrid C.F.: 'The new playing field is the world." The accompanying video presents an extended interview with Real Madrid's media director:

... Real Madrid has about 450 million fans. We are trying to give them all the feeling of being at the stadium. The Microsoft cloud gives us the scalability to communicate exactly the content that people want to see. Microsoft cloud allow us to establish a relationship that is more personal, is more direct with the fans ...

The third variant is focused on customer feedback. This variant solicits feedback and opinions from customers, both current and prospective, based on their needs, preferences, or experiences with company products and services. The following brand post from Honda (May 17) is a good example:

Have questions about the Honda College Grad Program? GradDad will be happy to answer any questions you have about buying a new Honda. Or any question you have, literally. Try it. Ask Away.

The attached link redirects customers to Honda's Financial Services page, where they can ask their questions.

To summarize, the customer relationship brand post category is crucial to strengthen customers' relation with the brand. These brand posts deliver customer services via social media channels, while also opening up new possibilities to listen to customers' opinions, preferences, expectations and experiences (Malthouse et al., 2013). Yet, despite their enormous potential to implement relationship marketing objectives, customer relationship brand posts are not particularly popular among the brands in our sample.

\subsection{Cause-related brand posts}

Cause-related brand posts highlight socially responsive programs and initiatives supported by the focal brand. These brand posts promote worthy social causes and encourage customers and fans to support them. Cause-related brand posts depict the focal brand in a positive light, often as a responsible entity that contributes to the proper functioning of society through impactful community programs. This brand post category accounts for $6 \%$ of the brand posts in the validation sample.

An example of cause-related brand posts is one by McDonald's from May 8: "Give a gift that keeps on giving! Become an everyday hero when you swing by your local restaurant now through May 10th-or share the lovin' online anytime!" The attached link redirects fans to a website, where they can give donation to support parents with hospitalized children. Another example is a brand post by Coca Cola (May 20): "When you support \#horizonsgivingday, you help create opportunities for more children to learn and grow! Check it out." The accompanying photo gallery shows young boys and girls engaged in different fun activities, while the attached link redirects fans to a blog post that discusses the virtues of summer learning and enrichment activities in uplifting underprivileged children's school performance.

Broadly speaking, cause-related brand posts promote various types of socially responsible corporate programs and initiatives. By embracing such programs, brands can leverage consumers' tendency to support worthy social causes. Moreover, cause-related brand posts possess considerable moral and emotional appeal that may motivate consumers to support the pertinent causes, while also cementing their commitment and emotional bond with the brand (Mangold \& Faulds, 2009). Overall, cause-related brand posts represent an important approach to create positive brand impressions. 


\subsection{Sales promotion}

These are brand posts that entice consumers to take actions toward a buying decision. Typically, sales promotion brand posts comprise transactional details such as price and availability points, as well as concrete promotional offers, such as price discounts, coupons and competitions. Sales promotion brand posts are often equipped with links to landing sites, where consumers can make purchases or sign up to promotional offers and competitions. The promotional brand post category accounts for $5 \%$ of the brand posts in the validation sample.

Among the few instances of sales promotion brand posts in our sample is a brand post by Honda from May 8:

We apologize in advance for getting this song stuck in your head. Here are some sweet deals to make up for it. Hurry into your local Honda dealership today though, because the deals end soon.

This text is accompanied by a parody music video featuring Honda robots and technicians, while the attached link redirects the user to a dedicated e-commerce website for Honda vehicles. Another example, which we came across during initial coding, is a brand post by American Express (May 21):

Fill your basket and save with Whole Foods Market and \#AmexOffers. Get $\$ 10$ back $1 x$ after you enroll and make a single purchase of $\$ 75+$ in-store and online at Whole Foods Market with your connected Amex Card.

The attached link redirects to an American Express website where consumers can sign up to the promotional program.

Overall, the promotional brand post category represents an important approach to drive sales through social media. However, the limited quantity of promotional brand posts in our sample reveals reluctance among corporate brands to pursue this approach. This does not mean that promotional brand posts are not popular elsewhere, however (Taecharungroj, 2016). For instance, in more narrowly defined and localized brand pages, promotional brand posts could be more popular, since consumers expect such offers (Pereira et al., 2014).

\section{Discussion and implication}

Brand posts are an essential element of brands' presence on social media (Lipsman et al., 2012). Brand posts are the principal vehicle through which brands maintain regular contact with their customers and fans on social media. Despite this crucial linking role, however, brand posts have rarely been subjected to formalized analyses. To help fill this gap in the literature, the present study conducted qualitative content analysis involving a combination of deductive, inductive, and validation coding. This layered coding procedure generated 12 exhaustive and mutually exclusive categories of brand posts.

The proposed categorization offers a comprehensive framework to think about brand posts. In particular for marketers, the proposed categories can be used to inspire new brand post ideas and stimulate daily customer interaction on social media. Further, marketers can employ the proposed categorization to fine-tune their content strategy. Among others, marketers can apply the proposed categorization to determine which categories of brand posts they publish frequently (vs. infrequently) and which categories of brand posts drive higher (vs. lower) levels of consumer engagement. Based on insights gained from such analyses, marketers could calibrate and refine their content strategy.

Moreover, the proposed categorization underscores the strategic value of brand pages. The categorization demonstrates how marketers can drive key marketing objectives through brand pages, from building product awareness (e.g. functional and educational brand posts) to simulating sales (e.g. promotional brand posts) to delivering post-purchase services (e.g. customer relationship brand posts) to building brand community (e.g. brand community and current-event brand posts). 
Marketers can also leverage brand pages to forge deeper personal and emotional connections with customers (e.g. emotional, personal and cause-related brand posts) and facilitate authentic brand experiences (e.g. brand resonance and experiential brand posts). Given these expanded possibilities to pursue multiple marketing objectives, it is imperative that marketers approach brand pages with the strategic orientation and commitment that they deserve.

For researchers, the proposed categorization offers a solid conceptual foundation to code, categorize and analyze brand posts. Researchers can draw on the proposed categorization to build and test sophisticated models of consumer engagement (Gensler et al., 2013; Peters et al., 2013). However, such an application calls for certain refinements. A key finding that emerged from our analysis is that brand posts often incorporate multiple messages into a single brand post. This complicates measurement and modeling efforts by making it harder for researchers (coders) to pin down individual brand posts to specific message categories. Hence, without a proper strategy, researchers may find it difficult to study the impact of brand posts effectively.

One approach would be to analyze brand posts that only employ a single message category. This approach could be particularly attractive for studies employing a large-scale sample of brand posts, where the attrition from eliminating brand posts with multiple messages could easily be offset. Nevertheless, this approach has the inevitable consequence of ignoring brand posts with multiple messages, which, as evidenced in our data-set, represent a substantial segment of marketers' brand post portfolio.

A more promising approach would be to merge individual brand post categories into major message categories. In this regard, the transformational vs. informational advertising messages could serve as a theoretically grounded starting point (Laskey et al., 1989; Puto \& Wells, 1984). While such brand post categories as emotional, experiential, brand resonance and social causes fit to the transformational message strategy, such brand post categories as educational, functional and employee brand posts fit to the informational message strategy (Puto \& Wells, 1984; Taylor, 1999). A new major message strategy could be created to accommodate the remaining brand post categories (i.e. current event, personal, brand community, and customer relationship). This new message strategy could be named interactional, for instance, to signify its emphasis on customer interaction on social media. By aggregating the 12 brand post categories into three major message strategies, researchers stand a better chance of isolating brand posts into distinct message strategies.

The development of broader message strategies (i.e. transformational, informational and interactional) opens up substantive opportunities for future research, where researchers can build and test managerially relevant models. A worthwhile effort in this respect would be to try to link the three major message strategies to consumer engagement, which is a principal outcome of interest on social media (Dessart, Veloutsou, \& Morgan-Thomas, 2016; Hollebeek, Glynn, \& Brodie, 2014). Similarly, future research could apply the three major message strategies to investigate possible differences in content strategy among different groups of brands (e.g. B2C vs. B2B brands; global vs. local brands; mass vs. luxury brands, and so on). A relevant example can be found in Swani et al. (2014), although the authors used an ad hoc categorization of brand posts. Finally, the three major message strategies could be mapped onto media type (i.e. text, photo, video, website links) to explore whether certain messages become more effective when delivered via certain media types. Will transformational messages become more effective when told through video, for instance? What about informational messages? Will they become more effective when they are communicated using photos? Although we were motivated to explore some of these research avenues ourselves, space limitation did not allow us to move beyond developing the proposed categorization. Therefore, we invite future researchers to explore these exciting research opportunities. 
Funding

The authors received no direct funding for this research.

\section{Author details}

Wondwesen Tafesse ${ }^{1}$

E-mail: wondwesen.tafesse@uit.no

Anders Wien

E-mail: anders.wien@uit.no

${ }^{1}$ School of Business and Economics, UIT the Arctic University

of Norway, Post Box 6050 Langnes, 9037 Tromsø, Norway.

\section{Citation information}

Cite this article as: A framework for categorizing social media posts, Wondwesen Tafesse \& Anders Wien, Cogent Business \& Management (2017), 4: 1284390.

\section{Notes}

1. A small fraction of brand posts are published as paid ads, but the vast majority of them reach consumers organically.

2. $I_{r}=\left\{\left[\left(F_{o} / N\right)-(1 / K)\right][k /(k-1)]\right\}^{0.5}$. For $F_{o} / N>1 / K$, where

$F=$ observed frequency of agreement, $N=$ total number of judgments and $K=$ number of coding categories.

3. The representative brand post examples cited in this section are summarized in an appendix. The appendix comprises screenshots and coding decisions for each brand post. Due to space constraints, however, the appendix could not be included here, but is available on request.

References

Ashley, C., \& Tuten, T. (2015). Creative strategies in social media marketing: An exploratory study of branded social content and consumer engagement. Psychology and Marketing, 32, 15-27. http://dx.doi.org/10.1002/mar.2015.32.issue-1

Barnes, N. G., \& Jacobsen, S. L. (2014). Missed eWOM opportunities: A cross-sector analysis of online monitoring behavior. Journal of Marketing Communications, 20, 147-158. http://dx.doi.org/10.1080/13527266.2013.797788

Berthon, P. R., Pitt, L. F., Plangger, K., \& Shapiro, D. (2012). Marketing meets Web 2.0, social media, and creative consumers: Implications for international marketing strategy. Business Horizons, 55, 261-271. http://dx.doi.org/10.1016/j.bushor.2012.01.007

Cvijikj, I. P., \& Michahelles, F. (2013). Online engagement factors on Facebook brand pages. Social Network Analysis and Mining, 3, 843-861. http://dx.doi.org/10.1007/s13278-013-0098-8

Davis, R., Piven, I., \& Breazeale, M. (2014). Conceptualizing the brand in social media community: The five sources model. Journal of Retailing and Consumer Services, 21, 468-481. http://dx.doi.org/10.1016/j.jretconser.2014.03.006

de Vries, L., Gensler, S., \& Leeflang, P. S. H. (2012). Popularity of brand posts on brand fan pages: An investigation of the effects of social media marketing. Journal of Interactive Marketing, 26, 83-91. http://dx.doi.org/10.1016/j.intmar.2012.01.003

De Vries, N. J., \& Carlson, J. (2014). Examining the drivers and brand performance implications of customer engagement with brands in the social media environment. Journal of Brand Management, 21, 495-515.

Dessart, L., Veloutsou, C., \& Morgan-Thomas, A. (2016). Capturing consumer engagement: Duality, dimensionality and measurement. Journal of Marketing Management, 32, 399-426. http://dx.doi.org/10.1080/0267257X.2015.1130738

Elo, S., \& Kyngäs, H. (2008). The qualitative content analysis process. Journal of Advanced Nursing, 62, 107-115. http://dx.doi.org/10.1111/j.1365-2648.2007.04569.x
Facebook. (2015). Facebook reports first quarter 2015 results. Retrieved August, 2015, from http://investor.fb.com/ releasedetail.cfm?ReleaseID $=908022$

Fournier, S., \& Avery, J. (2011). The uninvited brand. Business Horizons, 54, 193-207. http://dx.doi.org/10.1016/j.bushor.2011.01.001

Gensler, S., Völckner, F., Liu-Thompkins, Y., \& Wiertz, C. (2013). Managing brands in the social media environment. Journal of Interactive Marketing, 27, 242-256. http://dx.doi.org/10.1016/j.intmar.2013.09.004

Golan, G. J., \& Zaidner, L. (2008). Creative strategies in viral advertising: An application of Taylor's six-segment message strategy wheel. Journal of Computer-Mediated Communication, 13, 959-972. http://dx.doi.org/10.1111/jcmc.2008.13.issue-4

Graneheim, U. H., \& Lundman, B. (2004). Qualitative content analysis in nursing research: Concepts, procedures and measures to achieve trustworthiness. Nurse Education Today, 24, 105-112. http://dx.doi.org/10.1016/j.nedt.2003.10.001

Gummerus, J., Liljander, V., Weman, E., \& Pihlström, M. (2012). Customer engagement in a Facebook brand community. Management Research Review, 35, 857-877. http://dx.doi.org/10.1108/01409171211256578

Hollebeek, L. D., Glynn, M. S., \& Brodie, R. J. (2014). Consumer brand engagement in social media: Conceptualization, scale development and validation. Journal of Interactive Marketing, 28, 149-165. http://dx.doi.org/10.1016/j.intmar.2013.12.002

Hsieh, H., \& Shannon, S. E. (2005). Three approaches to qualitative content analysis. Qualitative Health Research, 15, 1277-1288. http://dx.doi.org/10.1177/1049732305276687

Jahn, B., \& Kunz, W. (2012). How to transform consumers into fans of your brand. Journal of Service Management, 23, 344-361. http://dx.doi. org/10.1108/09564231211248444

Kaplan, A. M., \& Haenlein, M. (2010). Users of the world, unite! The challenges and opportunities of Social Media. Business Horizons, 53, 59-68. http://dx.doi.org/10.1016/j.bushor.2009.09.003

Kietzmann, J. H., Hermkens, K., McCarthy, I. P., \& Silvestre, B. S. (2011). Social media? Get serious! Understanding the functional building blocks of social media. Business Horizons, 54, 241-251. http://dx.doi.org/10.1016/j.bushor.2011.01.005

Kim, D., Spiller, L., \& Hettche, M. (2015). Analyzing media types and content orientations in Facebook for global brands. Journal of Research in Interactive Marketing, 9, 4-30. http://dx.doi.org/10.1108/JRIM-05-2014-0023

Kolbe, R. H., \& Burnett, M. S. (1991). Content-analysis research: An examination of applications with directives for improving research reliability and objectivity. Journal of Consumer Research, 18, 243-250. http://dx.doi.org/10.1086/jcr.1991.18.issue-2

Laskey, H. A., Day, E., \& Crask, M. R. (1989). Typology of main message strategies for television commercials. Journal of Advertising, 18, 36-41 http://dx.doi.org/10.1080/00913367.1989.10673141

Lin, K., \& Lu, H. (2011). Why people use social networking sites: An empirical study integrating network externalities and motivation theory. Computers in Human Behavior, 27, 1152-1161. http://dx.doi.org/10.1016/j.chb.2010.12.009

Lipsman, A., Mudd, G., Rich, M., \& Bruich, S. (2012). The Power of "Like". Journal of Advertising Research, 52, 40-52. http://dx.doi.org/10.2501/JAR-52-1-040-052

Malthouse, E. C., Haenlein, M., Skiera, B., Wege, E., \& Zhang, M. (2013). Managing customer relationships in the social media era: Introducing the social CRM house. Journal of Interactive Marketing, 27, 270-280. http://dx.doi.org/10.1016/j.intmar.2013.09.008 
Mangold, W. G., \& Faulds, D. J. (2009). Social media: The new hybrid element of the promotion mix. Business Horizons, 52, 357-365. http://dx.doi.org/10.1016/j.bushor.2009.03.002

Muntinga, D. G., Moorman, M., \& Smit, E. G. (2011). Introducting COBRAs: Exploring motivations for brand-related social media use. International Journal of Advertising, 30, 13-46. http://dx.doi.org/10.2501/IJA-30-1-013-046

Pereira, H. G., de Fátima Salgueiro, M., \& Mateus, I. (2014). Say yes to Facebook and get your customers involved! Relationships in a world of social networks. Business Horizons, 57, 695-702. http://dx.doi.org/10.1016/j.bushor.2014.07.001

Perreault, W. D., \& Leigh, L. E. (1989). Reliability of nominal data based on qualitative judgments. Journal of Marketing Research, 26, 135-148. http://dx.doi.org/10.2307/3172601

Peters, K., Chen, Y., Kaplan, A. M., Ognibeni, B., \& Pauwels, K. (2013). Social media metrics-A framework and guidelines for managing media. Journal of Interactive Marketing, 27, 281-298. http://dx.doi.org/10.1016/j.intmar.2013.09.007

Puto, C. P., \& Wells, W. D. (1984). Informational and transformational advertising: The differential effects of time. Advances in Consumer Research, 11, 638-643.

Sabate, F., Berbegal-Mirabent, J., Cañabate, A., \& Lebherz, P. R. (2014). Factors influencing popularity of branded content in Facebook fan pages. European Management Journal, 32, 1001-1011. http://dx.doi.org/10.1016/j.emj.2014.05.001

Shen, B., \& Bissell, K. (2013). Social media, social me: A content analysis of beauty companies' use of Facebook in marketing and branding. Journal of Promotion Management, 19, 629-651. http://dx.doi.org/10.1080/10496491.2013.829160

Smith, A. N., Fischer, E., \& Yongjian, C. (2012). How does brandrelated user-generated content differ across Youtube, Facebook, and Twitter? Journal of Interactive Marketing, 26, 102-113. http://dx.doi.org/10.1016/j.intmar.2012.01.002

Swani, K., Brown, B. P., \& Milne, G. R. (2014). Should tweets differ from B2B and B2C? An analysis of Fortune 500 companies' twitter communications. Industrial Marketing Management, 43, 873-881.

http://dx.doi.org/10.1016/j.indmarman.2014.04.012
Taecharungroj, V. (2016). Starbucks' marketing communications strategy on Twitter. Journal of Marketing Communications, 1-19. http://dx.doi.org/10.1080/13527266.2016.1138139

Tafesse, W. (2015). Content strategies and audience response on Facebook brand pages. Marketing Intelligence \& Planning, 33, 927-943. http://dx.doi.org/10.1108/MIP-07-2014-0135

Tafesse, W. (2016). An experiential model of consumer engagement in social media. Journal of Product \& Brand Management, 25, 424-434.

Taylor, R. E. (1999). A six-segment message strategy wheel. Journal of Advertising Research, 39, 7-17.

Tuten, T. L., \& Solomon, M. R. (2015). Social media marketing (2nd ed.). Thousand Oaks, CA: Sage.

Van Noort, G., Antheunis, M. L., \& Verlegh, P. W. J. (2014). Enhancing the effects of social network site marketing campaigns: If you want consumers to like you, ask them about themselves. International Journal of Advertising, 33, 235-252. http://dx.doi.org/10.2501/IJA-33-2-235-252

Vernuccio, M., Pagani, M., Barbarossa, C., \& Pastore, A. (2015). Antecedents of brand love in online network-based communities. A social identity perspective. Journal of Product and Brand Management, 24, 706-719. http://dx.doi.org/10.1108/JPBM-12-2014-0772

Wallace, E., Buil, I., \& Chernatony, L. D. (2014). Consumer engagement with self-expressive brands: Brand love and WOM outcomes. Journal of Product \& Brand Management, 23, 32-42.

Walrave, M., Poels, K., Antheunis, M. L., Van den Broeck, E., \& van Noort, G. (2016). Like or dislike? Adolescents responses to personalized social network site advertising. Journal of Marketing Communications, 22, 1-18. http://dx.doi.org/10.1080/13527266.2016.1182938

Zaglia, M. E. (2013). Brand communities embedded in social networks. Journal of Business Research, 66, 216-223. http://dx.doi.org/10.1016/j.jbusres.2012.07.015

Zhang, Y., \& Wildemuth, B. (2009). Qualitative analysis of content. In B. Wildemuth (Ed.), Applications of social research methods to questions in information and library science (pp. 308-319). Westport, CT: Libraries Unlimited. 